\title{
ALLUVIAL SEDIMENT SOURCES IN A GLACIATED CATCHMENT: THE VOIDOMATIS BASIN, NORTHWEST GREECE
}

\author{
JAMIE C. WOODWARD* \\ The Godwin Laboratory, Sub-Department of Quaternary Research, University of Cambridge, Cambridge, CB2 $3 R S, U . K$. \\ JOHN LEWIN \\ Institute of Earth Studies, UCW Aberystwyth, Aberystwyth, Dyfed, SY23 3DB, U.K. \\ AND \\ MARK G. MACKLIN \\ Department of Geography, University of Newcastle, Newcastle-upon-Tyne, NEI 7RU, U.K.
}

Received 16 February 1990

Revised 23 August 1991

\begin{abstract}
X-ray diffraction (XRD) of the fine matrix component of four alluvial units and modern channel sediments in the Voidomatis River Basin of northwest Greece shows that fine sediment sources have changed considerably during the late Quaternary. The matrix fraction of the modern channel sediments is derived predominantly from erosion of local flysch rocks and soils. During the last glaciation, however, the fine sediment load of the Voidomatis River was dominated by glacially-ground, finely comminuted limestone materials. Limestone-derived fine sediment is not produced in significant amounts under modern climatic conditions. By combining this XRD work with a detailed programme of clast lithologic 1 analysis we have reconstructed former bedload and fine sediment load composition. The lithological properties of both the coarse $(8-256 \mathrm{~mm})$ and fine $(<63 \mu \mathrm{m})$ elements of the sediment load have varied markedly during the late Quaternary. A simple, semiquantitative assessment of fine sediment mineralogy, using diffractogram peak-height data, has provided a valuable complement to the information gathered from more traditional clast lithological techniques. Together, in favourable geological settings, fine fraction mineralogy and clast lithological analysis can provide a valuable tool for the reconstruction of late Quaternary alluvial environments.
\end{abstract}

KEY WORDS Alluvial stratigraphy Sediment sources X-ray diffraction Greece

\section{INTRODUCTION}

The reconstruction of Quaternary river environments and the lithological composition of their coarse sediment loads has attracted considerable scientific interest over the last two decades. Many investigations of coarse-grained Quaternary alluvial deposits have used 'clast lithological analysis' to identify catchment sediment source areas and, in combination with other information, to correlate or differentiate between geographically separated exposures ( $c f$. Rose and Allen, 1977; Bridgland, 1986). Clast lithological analysis or pebble counting has been a standard tool in studies of Quaternary alluvial history for many years and has furnished some impressively detailed reconstructions (e.g. Gibbard, 1985). In a similar way, but over much shorter timescales, a number of workers have shown that the mineralogy of fine river sediments can also be diagnostic of catchment source areas (Klages and Hsieh, 1975; Fan, 1976; Wood, 1978). In addition to mineralogy, a variety of other sediment properties have been used to trace fine sediment sources and

* Present address: Department of Geography, University of Exeter; Rennes Drive, Exeter, Devon, EX4 4RJ, U.K.

0197-9337/92/030205-12\$06.00

(C) 1992 by John Wiley \& Sons, Ltd. 
published examples include mineral magnetics (Walling et al., 1979; Oldfield et al., 1985), sediment colour (Grimshaw and Lewin, 1980), radionuclide activity (Peart and Walling, 1986) as well as palynology (Brown, 1985), heavy metal content (Lewin and Wolfenden, 1978; Macklin, 1985) and several other chemical properties (Peart and Walling, 1986). These and other studies have clearly demonstrated the utility of fine sediment properties for source ascription, at various scales, in several contrasting environments. However, despite a long established and growing interest in both fine sediment provenance and the nature of Quaternary river environments, comparatively little attention has focused upon fine sediment source variations over timescales longer than the last few centuries.

In fluvial systems the fine $(<63 \mu \mathrm{m})$ component of the sediment load is commonly transported in suspension and is therefore dispersed downstream very rapidly during flood events. Such material may become integrated into coarser channel sediments which have moved only a relatively short distance in any one flood event and are thus representative of localized sources, transported more slowly (cf. Lewin, 1981). It is therefore important to appreciate that the coarse and fine elements of any Quaternary alluvial fill may reflect the operation of quite different sediment sources and pathways.

Recent fieldwork in the Voidomatis River Basin in Epirus, northwest Greece, provided the opportunity to combine a clast lithological approach to alluvial history with an analysis of fine fraction $(<63 \mu \mathrm{m})$ mineralogy-attempting, in effect, to reconstruct former bedload and fine sediment load composition and to identify their respective source areas. The relatively simple geology of the Voidomatis catchment (generating a limited number of possible sediment sources) and the excellent natural exposures in late Quaternary alluvial sediments (allowing access to unmodified, fine matrix samples) presented an ideal study area in which to test the value of such an approach. In this paper we report a programme of bulk mineralogical analysis, using X-ray diffraction (XRD), on modern, late Holocene, and Pleistocene alluvial fine sediments ( $<63 \mu \mathrm{m}$ ) that form part of the sandy/silt matrix in a series of coarse-grained alluvial valley fills in the Voidomatis Basin.

\section{STUDY AREA: THE VOIDOMATIS BASIN}

\section{Geology and sediment sources}

The Voidomatis River rises on the western flank of the Pindus Mountains, draining a catchment of $384 \mathrm{~km}^{2}$ upstream of its confluence with the Aoos River in Epirus, northwest Greece. The Voidomatis is a 4th order, gravel-bed stream of steep average gradient $\left(0.016 \mathrm{~m} \mathrm{~m}^{-1}\right)$ reflecting the high relief of its catchment $(>2000 \mathrm{~m}$ ). In broad terms, the pre-Quaternary rocks of the Voidomatis Basin provide three main sources of river sediments (Figure 1). The limestones (Jurassic to Eocene) are hard, crystalline rocks with an insoluble residue component of $<0.5$ per cent (Woodward, 1990) which is typical of the pure, resistant carbonates of the wider Epirus region (Macleod, 1980; Smith and Moores, 1974). The upper members of this carbonate group contain occasional bands of cherty flint. In contrast the younger flysch rocks (Late Eocene to Miocene) consist of thin beds $(10-20 \mathrm{~cm})$ of graded sandstones intercalated with softer, fissile, yellow-brown siltstones. These rocks are rich in quartz and plagioclase and are locally tightly folded and deformed. To the southeast a small outcrop of the Pindus Ophiolite impinges on the basin providing clasts of tectonized harzburgite to the main Voidomatis channel via a steep tributary stream. This dense, ultramafic lithology has a distinctive mineral assemblage including olivine, pyroxene and spinel.

\section{Basin physiography}

While the geology of the catchment is thus fairly simple a series of distinctive physiographic units can be recognized. The upper basin (upstream of site B, Figure 1) is characterized by two contrasting sediment source areas. Firstly, the upland, headwater region east and northeast of the village of Tsepelovon (Figure 1) forms the highest part of the catchment and contains striking morphological and sedimentological evidence for recent Pleistocene glaciation. A series of $\mathrm{N}-\mathrm{S}$ trending, glacially-eroded, U-shaped valleys merge downslope into several large moraines with boulder-strewn surfaces. Numerous sections expose fresh, largely unweathered diamictons containing subrounded boulder- to gravel-sized clasts in a distinctive grey/white (calcite-rich) rock flour matrix (Figure 2). These features have been observed in the field by the authors and 


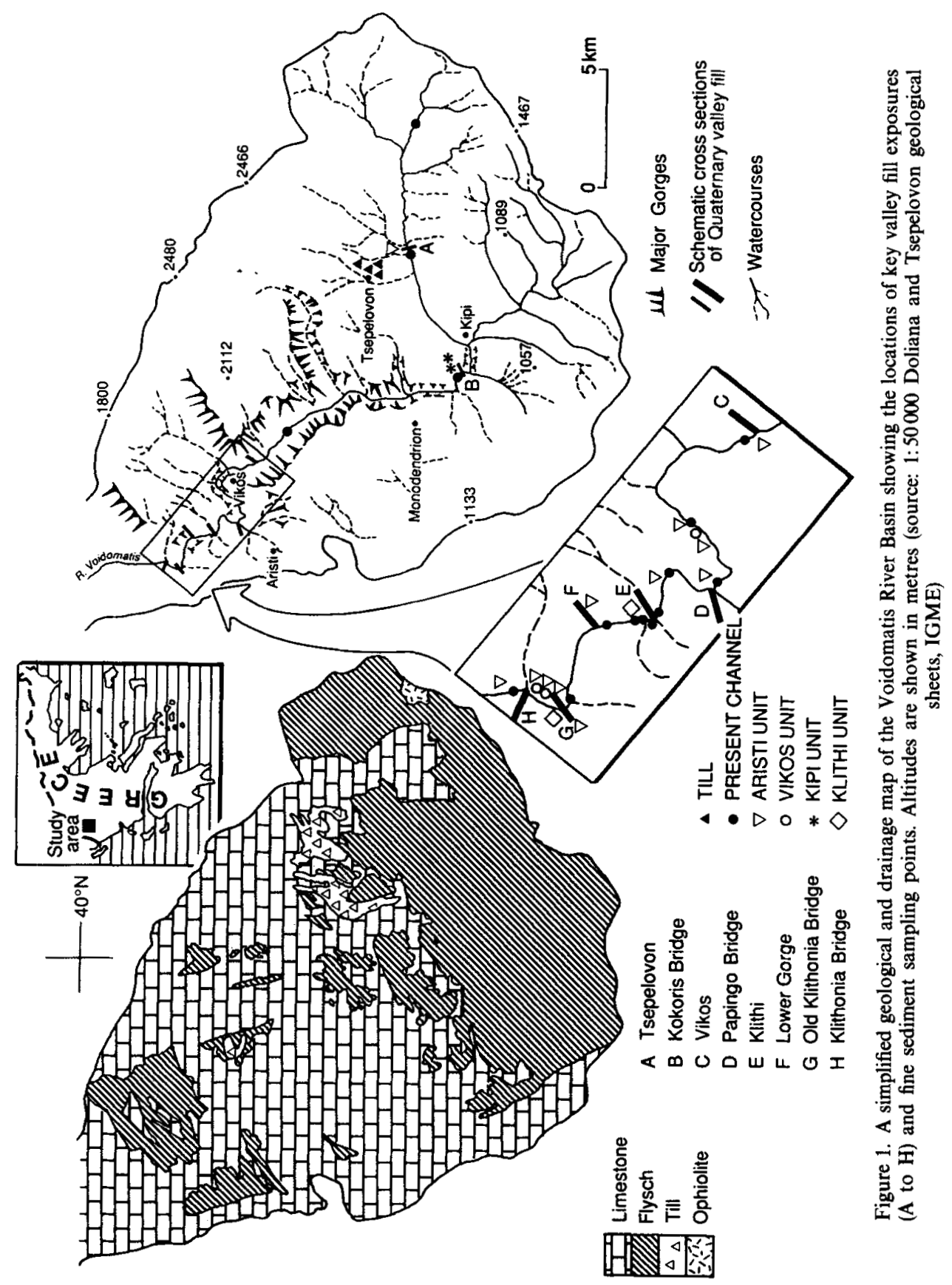



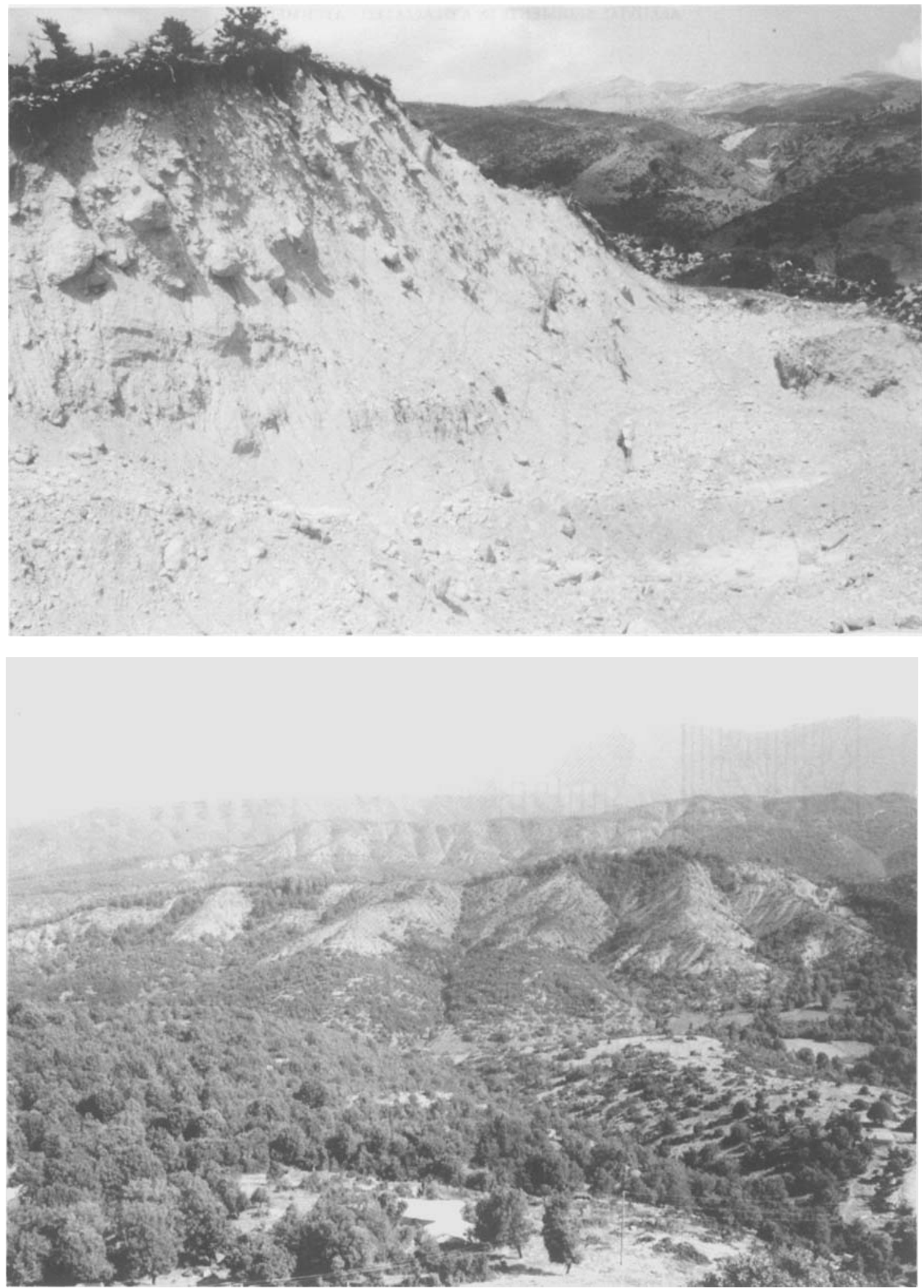

Figure 2. Top-a section in the Tsepelovon moraine complex exposing limestone-derived till sediments (figure for scale). Bottom--the flysch terrain in the southern headwaters of the catchment $(5 \mathrm{~m}$ telegraph pole in foreground for scale) 
the glacial landforms have also been identified using SPOT satellite imagery (Woodward, 1990). The glacial history of Greece is not well documented (Sibrava et al., 1986) and it is only very recently that the geomorphological and palaeoenvironmental significance of the northern Pindus glaciation has been investigated (Woodward, 1990; Lewin et al., 1991). Secondly, to the south, beyond the limits of recent glacial activity, the Voidomatis River drains a large area of flysch terrain (Figure 1). This area is characterized by a pinnate drainage pattern, with steep erosional slopes, producing a compact arrangement of short ridge and valley forms (Figure 2). Many of these slopes do not carry a continuous vegetation cover, are highly susceptible to erosion and provide an important source of easily erodible and transportable fine sediment. The central part of the catchment is dominated by the Vikos Gorge (Figure 1). This spectacular karst canyon is almost $900 \mathrm{~m}$ deep and lined with steep talus cones which frequently interfinger with a veneer of coarse alluvial sediments across the gorge floor. Immediately downstream the Lower Vikos Gorge is marked by a series of deeply incised meanders and a wider modern floodplain system. Several narrow tributary ravines drain the flysch exposures on either side of the Lower Vikos Gorge (Figure 1). In this part of the basin Quaternary river sediments and landforms are particularly well preserved. Downstream of the Old Klithonia Bridge (Figure 1, site G), the Voidomatis flows almost due north for $5 \mathrm{~km}$ across the Konitsa Plain, a broad, fault-controlled basin of low relief $(<20 \mathrm{~m})$, to its confluence with the River Aoos approximately $10 \mathrm{~km}$ from the Albanian border. On either side of the modern river this broad alluvial plain in mantled with coarse alluvial gravel deposits whose terraced surfaces lie between 5 and $10 \mathrm{~m}$ above modern river bed level.

\section{ALLUVIAL STRATIGRAPHY}

The late Quaternary alluvial history of the Voidomatis River has recently been described in detail by Lewin et al. (1991) and this information is summarized in Table I. In short, four lithologically distinct, terraced alluvial units, ranging in age from middle Pleistocene to late Holocene, have been identified in the basin. These sedimentary units have been differentiated in the field on the basis of clast lithology and altitudinal data (Table I) in addition to detailed observations of stratigraphical and morphological relationships which are particularly well exposed at eight key locations in the basin (Figure 3). The sedimentology and inferred

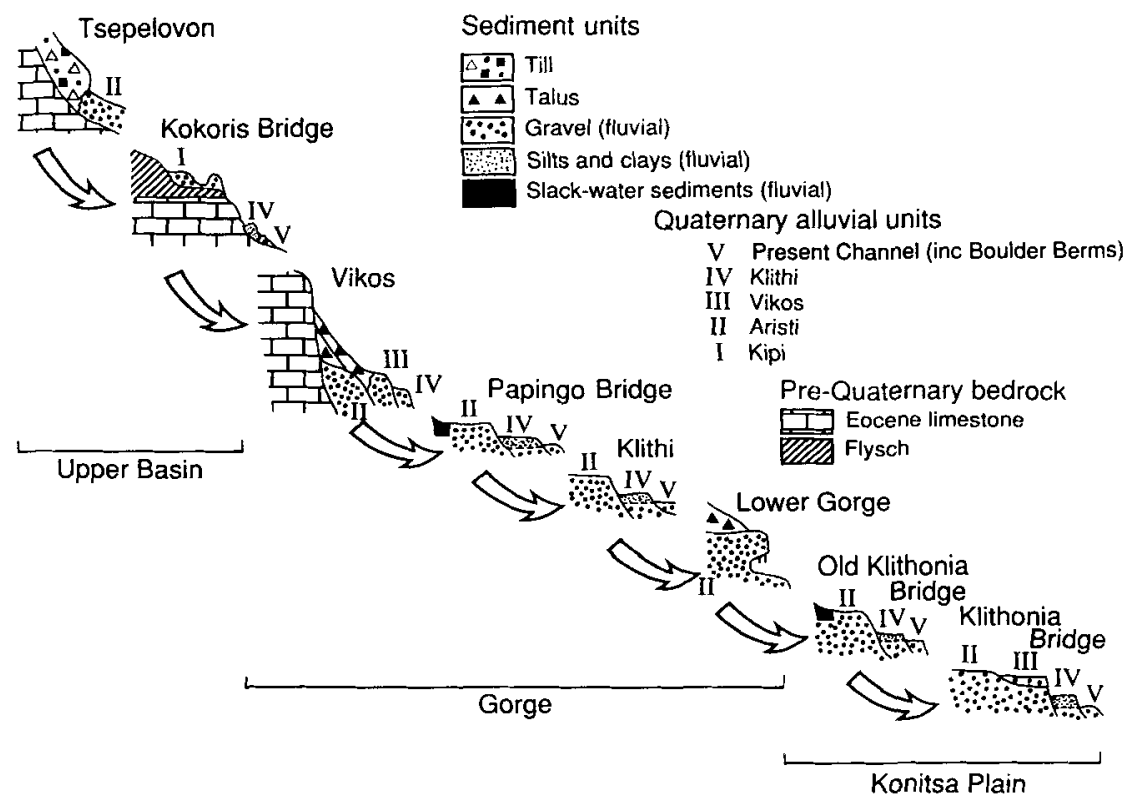

Figure 3. Schematic sections of the Quaternary valley fill sequence in the Voidomatis Basin. Site locations are shown in Figure 1 


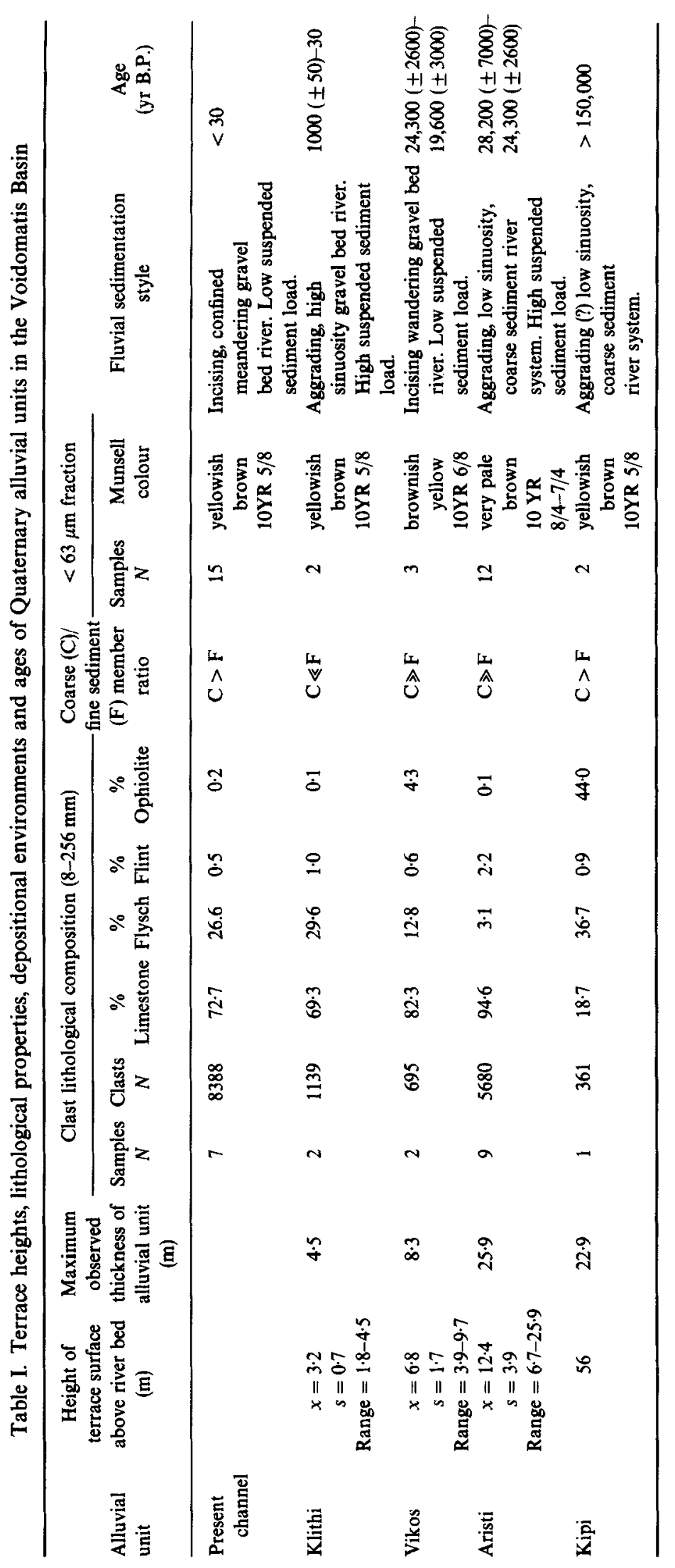


depositional environments of these units are discussed in Woodward (1990) and Lewin et al. (1991) and only an outline of their characteristics is presented here.

Kipi unit

This is the oldest alluvial unit in the basin, the terraced surface of which lies $56 \mathrm{~m}$ above the modern floodplain. It is the only alluvial unit where limestone clasts are subordinate to other lithologies (Table I). Ophiolite and flysch material dominate the gravel fractions. The large proportion of ophiolite clasts within this unit, in relation to the limited extent of this rock type in the modern catchment (Figure 1), suggests that the headwaters of this early river system may have been captured by the adjacent Aoos River. The Aoos drains an extensive region of ophiolite terrain immediately east of the modern Voidomatis catchment. A thermoluminescence (TL) date of $>150000$ years BP (VOI26) was obtained from silts close to the base of the section and provides a minimum age for the deposition of this unit.

\section{Aristi unit}

This is the major alluvial fill in the catchment since the gravels comprising this unit are the most extensive and have the largest volume of all the Voidomatis river sediments. Dominated by limestone, and up to $25.9 \mathrm{~m}$ above the modern river, the Aristi fill was formed as outwash derived from Late Pleistocene glaciation in the Tsepelovon district of the basin and is now a terraced remnant of the formerly extensive, aggrading, low-sinuosity pro-glacial river system. Three ESR dates from in situ red deer teeth of $24300 \pm 2600$ (571c), $25000 \pm 500(571 \mathrm{a})$ and $26000 \pm 1900(571 \mathrm{~b})$ years BP from the base of this unit and a TL date of $28200 \pm 7100$ years BP(VOI23) from the upper part of this unit indicate that deposition took place towards the end of the last glacial (Late Würmian) period (Bailey et al., 1990).

\section{Vikos unit}

In terms of sediment volume and areal extent now remaining this is a relatively minor unit. The terraced surface of these sediments lies between 4-9 $\mathrm{m}$ above the present floodplain. The Vikos unit gravels contain a significant component of ophiolite clasts (Table I). The matrix content of these gravels is generally lower than that of the Aristi sediments. Fine sediments in the upper part of this unit have been TL dated to $19600 \pm 3000$ years BP (VOI24).

\section{Klithi unit}

The terraced surface of this unit lies about $3 \mathrm{~m}$ above present river level. The Klithi sediments contain a similar clast composition to the modern floodplain gravels (Table I). The unit is composed of flat bedded, imbricated sandy gravels overlain by a distinctive fine-grained unit up to $2.5 \mathrm{~m}$ thick. This coarse/fine couplet is a 'type' example of a sedimentary sequence produced by lateral migration in a high-sinuosity meandering river (Jackson, 1978). Charcoal fragments from this unit on the Konitsa Plain have yielded radiocarbon dates of between $800 \pm 100(\mathrm{OxA}-192)$ and $1000 \pm 50(\mathrm{OxA}-191)$ years BP. However, organic deposits beneath $2 \mathrm{~m}$ of Klithi sediments in the Lower Vikos Gorge have been dated as modern $(102.7 \pm 1.2$ per cent OxA-1747, $c f$. Hedges et al., 1990). This indicates the continued development, at least locally, of this unit until quite recent times (Lewin et al., 1991).

\section{MATERIALS AND METHODS}

Samples of fine alluvial and glacial sediment (ca. $150 \mathrm{~g}$ ) were collected at the locations shown in Figure 1. At each site deep natural sections allowed access to unweathered matrix material. Fourteen bedrock samples (seven flysch and seven limestone) were selected from a larger hand specimen collection and are believed to be broadly representative of the lithological variations within the catchment. Rock samples were crushed and ground with a mortar and pestle to powders which would pass through a $63 \mu \mathrm{m}$ sieve. Alluvial and glacial sediments were air dried at room temperature and also screened through a $63 \mu \mathrm{m}$ sieve. Sample powders were mounted as slurries in an acetone solution on circular glass slips ( $20 \mathrm{~mm}$ diameter) and air dried at room temperature. This creates semirandomly orientated powder mounts and does not produce the maximum 
basal reflection intensities for the phyllosilicates. All samples were analysed under the same instrument conditions using a Philips PW 1730 X-ray generator and PW 1050/25 vertical goniometer. In total, 14 bedrock and 38 Quaternary sediment samples were prepared and coanalysed by XRD. The resulting diffractograms were interpreted using published XRD tables in Brown and Brindley (1980). Of particular interest to this study are the fluctuations in the relative proportions of quartz and plagioclase, and calcite, which serve as a useful proxy for the respective flysch and limestone contributions. Peak-height measurements were recorded for quartz $4 \cdot 26 \AA(100 \mathrm{hkl})$, plagioclase $3 \cdot 196 \AA(002 \mathrm{hkl})$, and calcite $2 \cdot 095 \AA$ (202 hkl), on all diffractogram traces for comparative analysis. Although estimates of mineral abundance obtained by this method are no more than relative and semiquantitative, they provide an extremely useful means for comparing intersample composition (cf. Griffin, 1971; Wood, 1978).

\section{ALLUVIAL SEDIMENT SOURCES IN THE VOIDOMATIS BASIN}

The mineralogy of the three major sediment sources within the basin is shown in Figure 4. The limestone and flysch rocks are composed of different mineral suites although most samples contain calcite, plagioclase and quartz in varying amounts. The glacial sediments of the Tsepelovon district are almost exclusively limestonederived. The brilliant white colour of these sediments (Figure 2) and the XRD traces shown in Figure 4 indicate a limestone source for the fine matrix (rock flour) component. These deposits, however, do contain a very minor flysch gravel component and an increase in quartz and plagioclase also reflects the presence of a minor flysch component in the $<63 \mu$ m matrix.

It is well known that both mineralogy and texture exert a strong influence upon rock fragmentation rates. Equally, these parameters and the processes operating at the bedrock surface determine the amount and calibre of any breakdown products. Thus, in very general terms, source material properties and the nature of the breakdown environment control the size, form and quantity of sediment particles available for subsequent fluvial transport. For example, whereas chalky or marly limestones can liberate much fine material, the limestones of the Voidomatis Basin are generally hard, resistant rocks with few impurities. These rocks currently provide large quantities of coarse alluvial (Figure 5) and colluvial material, but liberate only small amounts of fine $(<63 \mu \mathrm{m})$ sediment. In marked contrast, the local flysch rocks include interbedded strata of quartz-rich, graded sandstones, which provide coarse, tabular, alluvial material, and

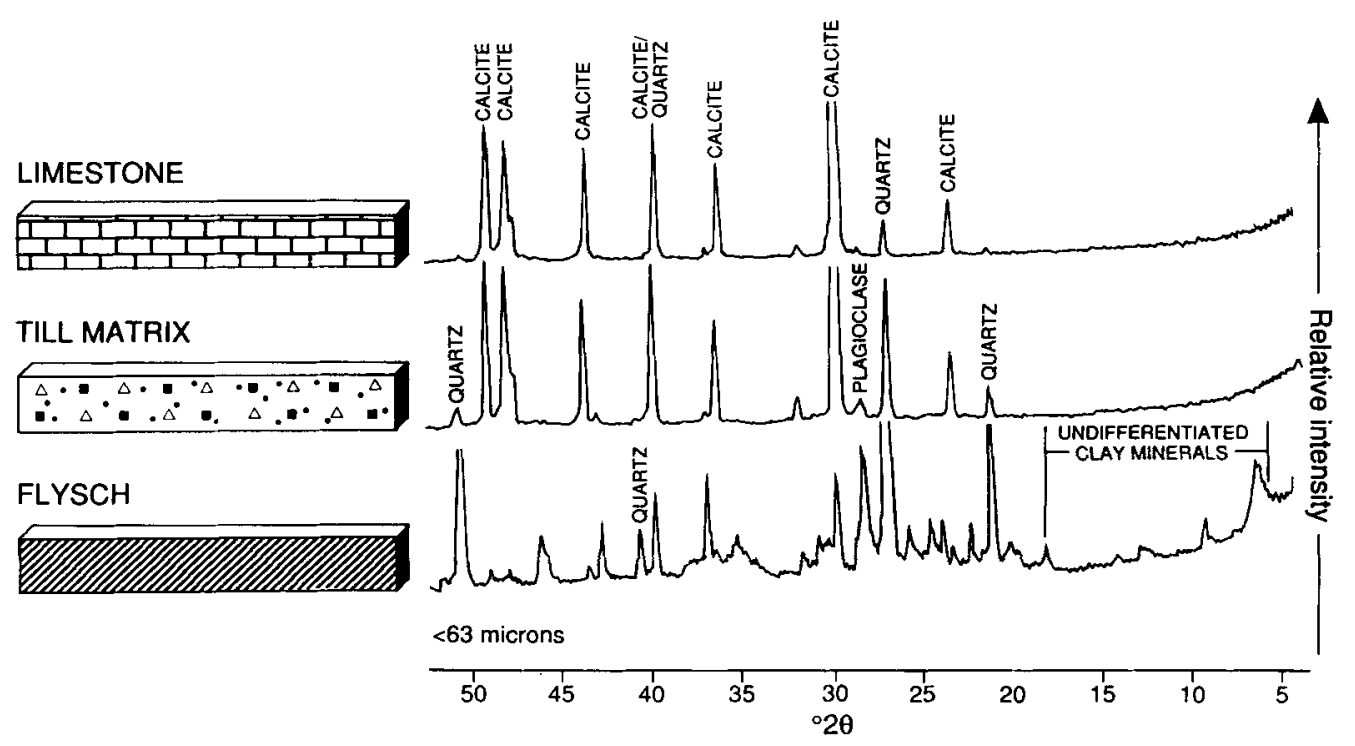

Figure 4. Typical X-ray diffraction traces for the three major sources of fine alluvial sediment in the Voidomatis Basin 


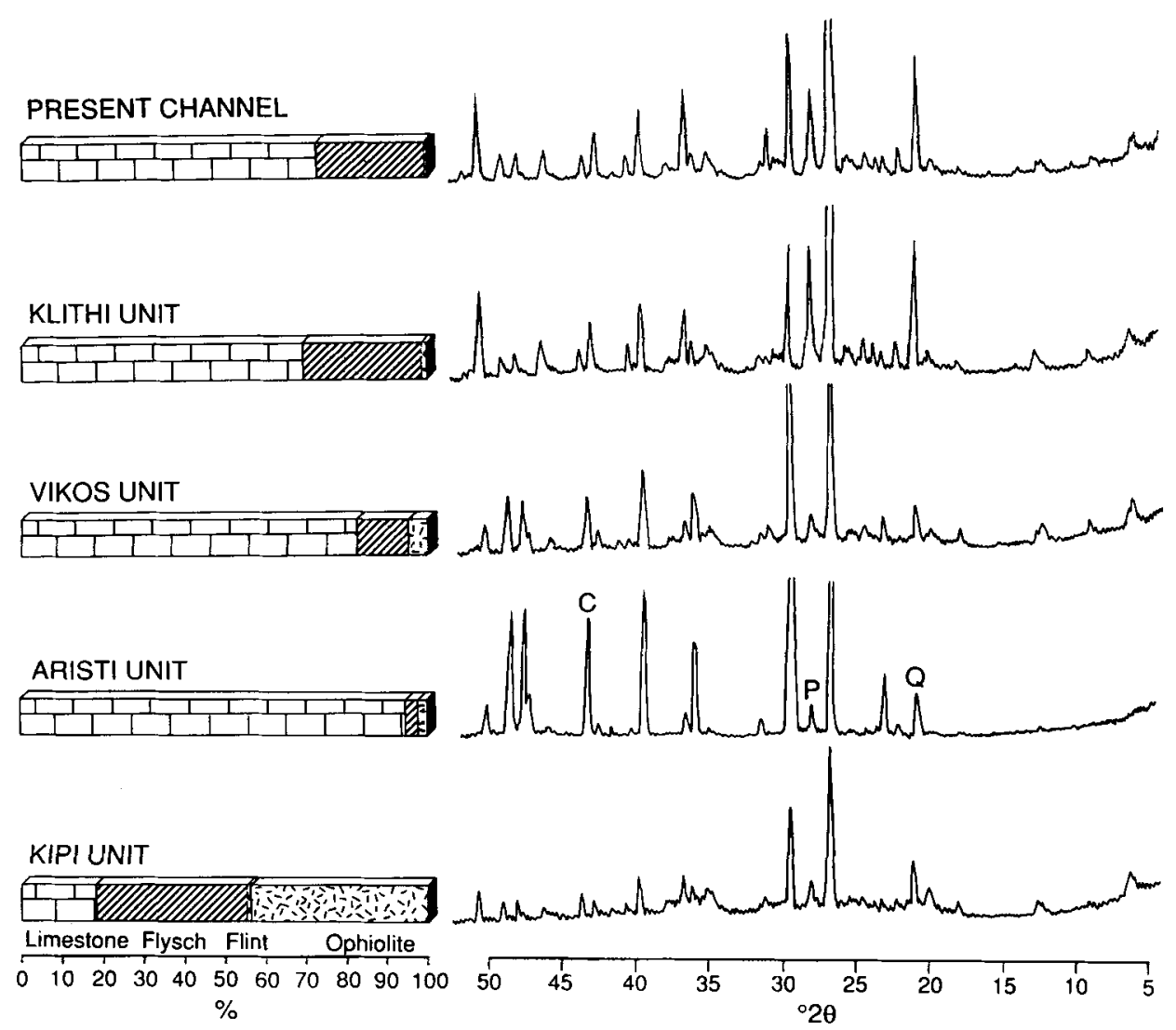

Figure 5. The lithological composition of the coarse and fine components of the Voidomatis alluvial sediments. Typical bulk mineralogy XRD traces showing the peaks used for comparative analysis in Figure 6: C-2.095 $\AA$ (202 hkl) calcite peak, Q-4.26 $\AA$ (100 hkl) quartz peak, $\mathrm{P}-3.196 \AA(002 \mathrm{hkl})$ plagioclase feldspar peak. Flysch-derived phyllosilicates are either absent or are present in only very small quantities in the Aristi unit samples

brittle, fissile siltstones which supply an abundance of easily erodible and transportable clastic material in the $<63 \mu \mathrm{m}$ grade.

Figure 6a shows the strong positive relationship $\left(r^{2}=0.86\right)$ between quartz and plagioclase in the basin sediments. In general, an increase in this mineral pair in the Quaternary sediments signals an increase in the contribution from the catchment flysch. This plot indicates that significant changes in fine sediment composition have taken place since the last glaciation. Calcite and plagioclase relationships can be used to discriminate basin sediment source components, differentiating between limestone/till and fiysch (Figure 6b). In the same way, plagioclase and calcite relationships can be used to highlight the contrast in fine sediment composition between the contemporary Voidomatis River and the Late Pleistocene, full-glacial system as represented by the Aristi unit sediments (Figure 6c).

\section{LATE QUATERNARY ENVIRONMENTAL CHANGE AND FINE SEDIMENT SOURCE VARIATIONS}

The fine sediment load of the modern Voidomatis River is derived almost exclusively from erosion of local flysch rocks and soils (Figure 6a). Even though limestone material dominates the gravel fractions of the 

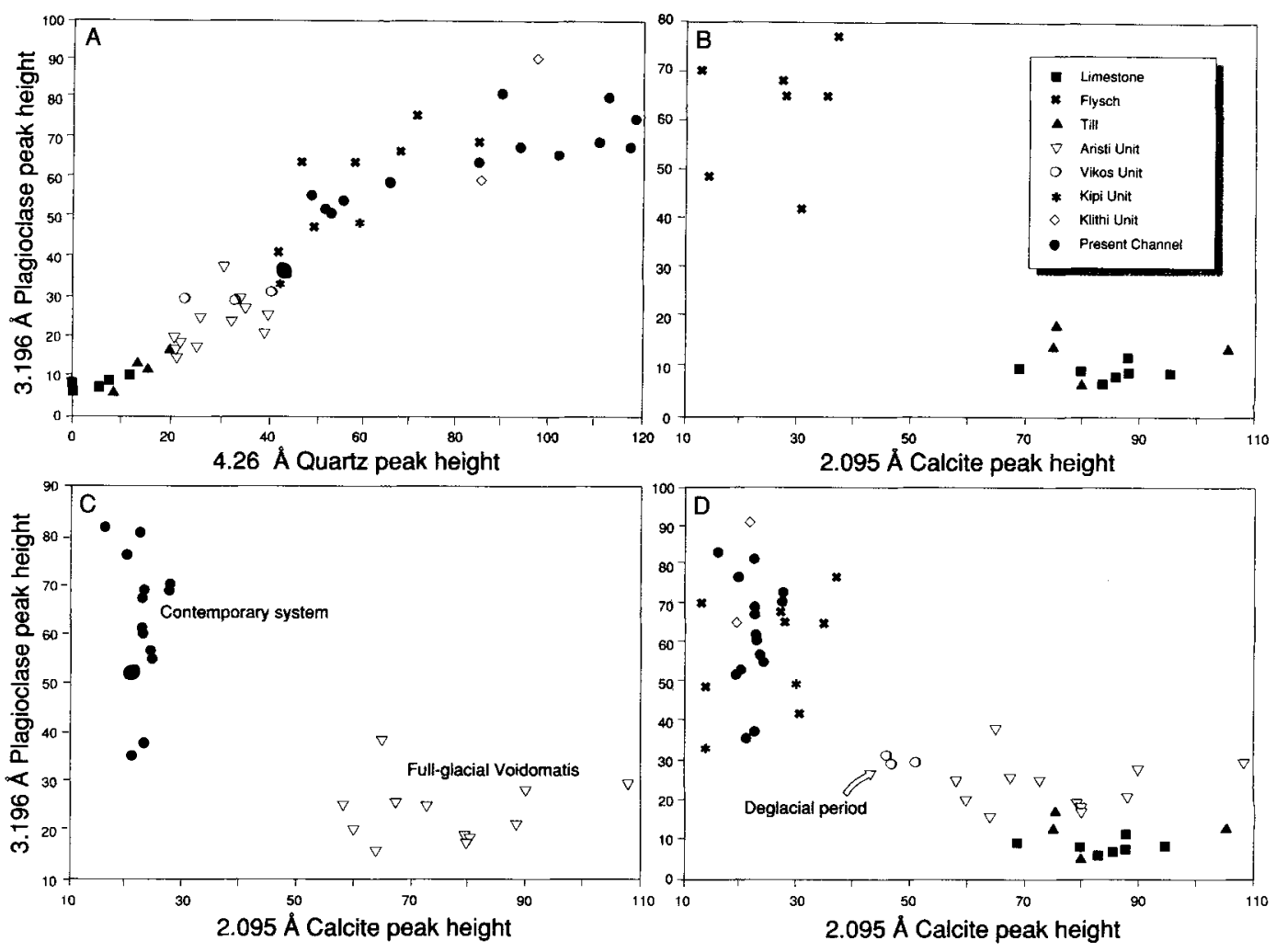

Figure 6. (a) Plot showing the positive correlation between plagioclase and quartz in the basin sediments. (b) The major sources of alluvial fine sediments identified on the basis of plagioclase and calcite relationships. (c) The contemporary Voidomatis River and the cold stage, glaciated system (compare with source data in 6b). (d) Summary plot including all the XRD data for source materials and alluvial sediments. While the contemporary floodplain sediments are relatively well defined in terms of the calcite peak height, the scatter evident in both the plagioclase and quartz peak heights may be partly explained by intersample variations in the particle size assemblage.

modern river and the Klithi unit (Figure 5), it does not liberate significant amounts of sediment $<63 \mu \mathrm{m}$ under modern climatic conditions. In contrast, the fine matrix of the Late Pleistocene Aristi gravels is dominated by limestone-derived sediment as indicated by plagioclase-quartz (Figure 6a) and plagioclase-calcite relationships (Figure 6c, 6d). The high fine sediment load of this unit results from the ready availability of large quantities of loosely consolidated glacial detritus (till) in the headwaters of the catchment. The physical processes of grinding, crushing and abrasion, which dominate the glacial environment, combine to comminute even the most resistant rocks and may produce vast quantities of rock flour. It might also be considered, however, that periglacial weathering during the Late Pleistocene would be capable of generating mechanically-reduced rock particles in sufficient quantity to account for the supply of appropriate volumes and sizes of alluvial materials. Indeed, subaerial (freeze-thaw) weathering of limestone cliffs has clearly been important in the development of the extensive talus slopes of the Vikos gorge, and these formations present a potentially important source of coarse alluvial sediment. However, as far as the fine $(<63 \mu \mathrm{m})$ component is concerned, we believe that glacial grinding has been the most important process in producing the large volume of limestone-derived sediment which dominates the matrix fraction of the Aristi unit gravels.

Contemporary weathering processes involve solutional decay of the basin limestones and material $<63 \mu \mathrm{m}$ is not a major constituent of recent (limestone) breakdown products. Thus, while the limestone 
beds supply large amounts of rudaceous material, any limestone-derived clastic sediment $<63 \mu \mathrm{m}$ is largely removed in solution in the modern river. The flysch beds of the catchment support a relatively high density, surface drainage network (Figure 1) and extensive flysch terrain in the southern part of the basin displays many characteristics of a 'badlands' landscape. Consequently, in the modern and late Holocene systems, alluvial fine sediments are primarily of flysch origin. Further south in Epirus, recent mineralogical and particle-size information from the 'Valley-floor Alluvium' in the Louros valley also indicates that flyschderived soils are the major source component of recent fine alluvial sediments (Macleod and Vita-Finzi, 1982). This marked contrast between the modern system and the cold stage, glacial Voidomatis is shown in Figure $6 \mathrm{c}$. This simple provenance information highlights the dramatic influence of Pleistocene glaciation upon this basin-sediment system, whereby extensive glacial erosion of the upland, headwater limestones completely transformed the geometry and lithology of alluvial sedimentation. The limestone and flysch gravel components of the Vikos unit are intermediate in composition between the Aristi unit and the modern floodplain sediments (Figure 5). Mineralogically, the Vikos unit fine sediments are also intermediate between those of the Aristi unit and the modern Voidomatis floodplain deposits (Figure 6a and 6d). The composition of the Vikos unit fine sediments indicates that glacially-modified (finely comminuted), calcite-rich material was still being delivered to the fluvial system during the deposition of this fill, either directly, from glacial activity, or through reworking of existing Aristi sediments. The Vikos unit sediments may represent a period of deglaciation (Lewin et al., 1991). The predominance of coarse limestone clasts in the three post-Aristi alluvial units (Figure 5) may partly reflect the progressive reworking of Aristi unit sediments, since this coarse material is transported relatively slowly through the delivery system. These sediments are thus prone to repeated phases of reworking and long-term storage. It can be argued that the highly mobile fine sediments are largely representative of contemporaneous patterns of catchment-wide erosion, while the relative proportions of coarse clast lithologies may be partly conditioned by antecedent catchment conditions.

Figure 6d shows all the XRD data including two samples collected from the base of a $22.9 \mathrm{~m}$ exposure in the Kipi unit. The mineralogy of the ophiolite, the source material which dominates the Kipi gravels, includes olivine and orthopyroxene. These minerals weather very rapidly in a subaerial environment and do not make a significant contribution to the alluvial fine fraction. The composition of the Kipi unit fines suggests that eroding flysch basins were the major source of fine sediments at this time. Figure $6 \mathrm{~d}$ also highlights the last glacial-to-interglacial transition as recorded in the Voidomatis fine sediments. As the Late Pleistocene climate of the basin ameliorated, glacial activity waned and the delivery of glacially-modified fines eventually ceased, allowing fiysch sediments to dominate the fine sediment load of the postglacial river. This transition, from limestone- to flysch-dominated fine sediment, is also apparent in the colour of the $<63 \mu \mathrm{m}$ fraction of these alluvial units (Table I) which also corresponds with a progressive increase in flysch bedload (Figure 5).

\section{CONCLUSIONS}

1. The lithological composition of the coarse and fine elements of the Voidomatis alluvial units has varied significantly during the late Quaternary and these variations reflect changes in sediment source areas.

2. The large quantity of limestone-derived fine sediment within the Aristi unit gravels is the product of glacial grinding - the dense, crystalline carbonates of the basin could only liberate rock flour in such quantities when subjected to comminution processes in a glacial environment. The dominance of coarse limestone material in the modern river gravels may partly reflect the progressive reworking of Aristi unit sediments.

3. A consideration of source material properties and the calibre of their erosional products preserved in Quaternary alluvial sedimentary sequences may allow valuable inferences about past geomorphological processes to be made. Together, in favourable geological settings, clast lithological analysis and fine sediment mineralogy provide a useful tool for the reconstruction of late Quaternary alluvial environments.

4. In this study a simple, semiquantitative assessment of fine sediment composition has provided a valuable complement to the information gathered from clast lithology. In a broader context, however, it is important to recognize that the fine matrix component of coarse alluvial sediments will not, in most cases, be truly representative of the overall suspended load but may nevertheless provide a useful indication of its nature and origin. Furthermore, if this approach is to be of value in other catchment-scale studies, 
particularly where greater lithological diversity is likely, a more rigorous and quantitative evaluation of mineralogical composition would be required. The utility of this approach will clearly diminish in studies of progressively older sediments since the availability of unaltered fine sediments will decrease with age at a rate dependent upon the particular weathering environment.

\section{ACKNOWLEDGEMENTS}

We thank Geoff Bailey for inviting us to join the Klithi Archaeological project and IGME, Athens, for permission to undertake fieldwork in Epirus. This work was carried out while JCW was in receipt of a SERC Ph.D studentship at Darwin College. The Department of Earth Sciences, Cambridge, provided access to XRD facilities. The authors are grateful to Phil Gibbard, Ken Pye, Des Walling and two anonymous referees for valuable comments on the manuscript. Terry Bacon and Andrew Teed of the Exeter University Geography Department kindly prepared the diagrams and photographs respectively. This is publication number 158 of the Institute of Earth Studies, UCW Aberystwyth.

\section{REFERENCES}

Bailey, G. N., Lewin, J., Macklin, M. G. and Woodward, J. C. 1990. 'The “Older Fill” of the Voidomatis Valley, northwest Greece, and its relationship to the Palaeolithic archaeology and glacial history of the region', Journal of Archaeological Science, 17, $145-150$.

Bridgland, D. R. 1986. Clast Lithological Analysis, Technical Guide No. 3, Quaternary Research Association, Cambridge, 207 pp.

Brown, A. G. 1985. 'The potential use of pollen in the identification of suspended sediment sources', Earth Surface Processes and Landforms, 10, 27-32.

Brown, G. and Brindley, G. W. 1980. 'X-ray diffraction procedures for clay mineral identification', in Brindley, G. W. and Brown, G. (Eds), Crystal Structures of Clay Minerals and their X-ray identification, Mineralogical Society, London, $305-359$.

Fan, Pow-Foong 1976. 'Recent Silts in the Santa Clara river drainage basin, southern California: a minerological investigation of their origin and evolution', Journal of Sedimentary Petrology, 46, (4), 802-812.

Gibbard, P. L. 1985. The Pleistocene History of the Middle Thames Valley, Cambridge University Press, Cambridge, $155 \mathrm{pp}$.

Griffin, G. M. 1971. 'Interpretation of X-ray diffraction data', in Carver, R. E. (Ed.), Procedures in Sedimentary Petrology, John Wiley, New York, 541-569.

Grimshaw, D. L. and Lewin, J. 1980. 'Source identification for suspended sediments', Journal of Hydrology, 47, 151-161.

Hedges, R. E. M., Housley, R. A., Bronk, C. R. and van Klinken, G. J. 1990. 'Radiocarbon dates from the Oxford AMS system: Archaeometry datelist 11', Archaeometry, 32, 211-237.

Jackson, R. G. 1978. 'Preliminary evaluation of lithofacies models for meandering alluvial streams', in Miall, A. D. (Ed.), Fluvial Sedimentology. Canadian Society of Petroleum Geologists Memoir, 5, 543-577.

Klages, M. G. and Hsieh, Y. P. 1975. 'Suspended solids carried by the Gallatin River of southwestern Montana: II. Using mineralogy for inferring sources', Journal of Environmental Quality, 4, 68-73.

Lewin, J. 1981. 'Contemporary erosion and sedimentation', in Lewin, J. (Ed.), British Rivers, George Allen and Unwin, London, $34-58$.

Lewin, J. and Wolfenden, P. J. 1978. 'The assessment of sediment sources: a field experiment', Earth Surface Processes, 3, $171-178$.

Lewin, J., Macklin, M. G. and Woodward, J. C. 1991. 'Late Quaternary fluvial sedimentation in the Voidomatis Basin, Epirus, northwest Greece', Quaternary Research, 35, 103-115.

Macklin, M. G. 1985. 'Flood-plain sedimentation in the upper Axe Valley, Mendip, England', Transactions Institute British Geographers, 10, 235-244.

Macleod, D. A. 1980. 'The origin of the red Mediterranean soils in Epirus, Greece', Journal of Soil Science, 31, $125-136$.

Macleod, D. A. and Vita-Finzi, C. 1982 . 'Environment and provenance in the development of recent alluvial deposits in Epirus, northwest Greece', Earth Surface Processes and Landforms, 7, 29-43.

Oldfield, F., Maher, B. A., Donoghue, J. and Pierce, J. 1985. 'Particle size related, mineral magnetic source sediment linkage in the Rhode River Catchment, Maryland, USA', Journal of the Geological Society, 142, 1035-1046.

Peart, M. R. and Walling, D. E. 1986. 'Fingerprinting sediment sources: the example of a small drainage basin in Devon, UK', in Drainage Basin Sediment Delivery, Proceedings of the Albuquerque Symposium. IAHS Publication 159, 41-55.

Rose, J. and Allen, P. 1977. 'Middle Pleistocene stratigraphy in southeast Suffolk', Journal of the Geological Society, 133, 83-102.

Sibrava, V., Bowen, D. Q. and Richmond, G. M. 1986. 'Quaternary Glaciations in the Northern Hemisphere', Quaternary Science Reviews, 5.

Smith, A. G. and Moores, E. M. 1974. 'Hellenides', in Spencer, R. A. (Ed.), Mesozoic and Cenozoic Orogenic Belts. Special Publication of the Geological Society of London, 4, 159-185.

Walling, D. E., Peart, M. R., Oldfield, F. and Thompson, R. 1979. 'Suspended sediment sources identified by magnetic measurements', Nature, 281, 110-113.

Wood, P. A. 1978. 'Fine sediment mineralogy of source rocks and suspended sediment, Rother catchment, West Sussex', Earth Surface Processes, 3, 255-263.

Woodward, J. C. 1990. Late Quaternary Sedimentary Environments in the Voidomatis Basin, Northwest Greece, Unpublished Ph.D Thesis. University of Cambridge. 